Proc. Estonian Acad. Sci. Biol. Ecol., 2001, 50, 2, 53-65

\title{
HISTORY OF MARINE RESEARCH IN ESTONIA
}

\author{
Evald OJAVEER
}

Estonian Marine Institute, Viljandi mnt. 18B, 11216 Tallinn, Estonia; eojaveer@ ness.sea.ee

Received 6 April 2001

\begin{abstract}
Estonian marine research started with investigations of remote seas mainly by the Baltic German noblemen in the 18th century. In the first half of the 19th century measurements of the sea level were started in the Tallinn Port (1805), and the salinity and temperature were determined in some areas of the Estonian coastal sea. In the early 1850 s K. E. von Baer carried out probably the first large-scale studies on overfishing of marine fish stocks in the world. After the Estonian War of Independence, in the 1920s-30s, fisheries research developed and regular monitoring cruises were performed in Estonian waters. Estonian occupation in 1940 disrupted the work. In World War II the losses of Estonian marine science were very great. In 1944 the Estonian Department of the AllUnion Research Institute of Marine Fisheries and Oceanography was founded. The institution was repeatedly reorganized, being subordinated to the Academy of Sciences of the Estonian SSR, the Baltic Fisheries Research Institute (in Riga), etc. Marine studies were also performed by the Section/Department of the Baltic Sea (founded in 1972) and the Section of Marine Biology (founded in 1974) of the institutes of the Academy of Sciences of the Estonian SSR, and elsewhere. Important scientific and practical results were achieved, a number of theses promoted, and publications produced. Strong staff of scientists allowed the formation of the Estonian Marine Institute after Estonia regained independence. The Institute has developed good international collaboration, especially in the framework of the International Council for the Exploration of the Sea (ICES), to which Estonia belongs as a full member since 1994. In 2001 the Institute was affiliated to the University of Tartu.
\end{abstract}

Key words: marine/fisheries research, Estonian Laboratory of Marine Ichthyology, Tallinn Department of the BaltNIIRH, Estonian Marine Institute, Section/Department of the Baltic Sea, Section of Marine Biology.

\section{INTRODUCTION}

Estonian population and area are rather small. However, our coastline is long - together with the islands about $3800 \mathrm{~km}$. Therefore, marine transportation, fisheries, and fishing industry as well as the business connected with seaside health resorts, holiday centres, and sports facilities are important activities in Estonia offering livelihood for a substantial fraction of the population. For all these activities the condition of the sea and its changes under the influence of natural processes and human impact are of great significance. Therefore, physical 
and chemical processes and the life forms in the sea, especially the dynamics of fish and seal stocks, changes in invertebrate and macrovegetation resources, as well as dangerous substances in the water, sediments, and organisms, are the subjects of careful studies and continuous monitoring. As seas are common for a number of countries, their investigation and management are regulated with international conventions and agreements compulsory for member countries.

Below a brief survey of the complicated path of development of marine science in Estonia during different periods of history is presented (see Appendix).

\section{MARINE INVESTIGATIONS IN ESTONIA AS A PART OF TSARIST RUSSIA}

In Estonia studies of the sea started as early as at the beginning of the 19th century with the exploration of remote seas. The most outstanding researchers belonged among Baltic German noblemen (born and buried in Estonia): Admiral A. J. von Krusenstern (the leader of the first Russian round-the-world voyage, 1770-1846), Admiral F. G. von Bellingshausen (1778-1852), O. von Kotzebue (1787-1846), Admiral F. von Wrangel (1797-1870), etc. A well-known Canadian researcher of the Beaufort Sea, a native Estonian G. Masik (A. Maasik, 18871919) should also be included into this group (Ojaveer et al., 2000).

The first systematic measurements of sea level started at the Tallinn Port in 1805. The first samples for determination of salt content in the Baltic Sea water were collected in Tallinn and Haapsalu bays in the early 1840s. Data on the composition of macrovegetation at the Estonian coasts of the Baltic Sea were published by Prof. K. E. Eichwald in Moscow in the middle of the 19th century. The first marine expedition in Estonian waters was arranged by Professor of the University of Tartu M. Braun from June to November 1884. During the expedition bottom fauna, plankton, macrovegetation, and the environmental conditions (salinity, temperature) were investigated in the Gulf of Finland, Väinameri, and the open sea north of Hiiumaa (Braun, 1884; Mardiste, 1995).

In the 19th century the most important investigations on the living resources in the Estonian waters of the Baltic Sea were performed by K. E. von Baer, who studied possible overfishing in lakes Peipsi and Pskov and in Estonian and Livonian waters of the Baltic Sea starting from 1851 (Baer, 1860). The studies carried out in the area from the estuary of the Luga River in the Gulf of Finland to the mouth of the Daugava River in the Gulf of Riga (including the coasts of Saaremaa and Hiiumaa) were probably the first large-scale studies on overfishing of marine fish stocks in the world.

\section{IN THE REPUBLIC OF ESTONIA UNTIL WW II}

Regular oceanographic investigations started in Estonian waters after the War of Independence. The plans for these explorations were composed on a meeting 
of Estonian, Finnish, and Latvian leading specialists in Tallinn in October 1921. It was hoped that the studies could be arranged in collaboration with the International Council for the Exploration of the Sea (ICES). Therefore, in data collection the methods in use in ICES were followed. Yearly monitoring cruises on board coasters for hydrological and hydrochemical studies in the stationary stations (Fig. 1) were started in 1923 by Professor of the University of Tartu Karl Frisch (from 1935 Kaarel Kirde, 1892-1953). They were continued up to 1939. During the cruises in 1924-30 also plankton investigations were carried out by Professor of the University of Tartu Heinrich Riikoja (1891-1988) (Frisch \& Riikoja, 1925; Kirde, 1940).

Ichthyological investigations were connected with the University of Tartu. Mainly fish migrations were studied. Fisheries research intensified after 1936 when the Fisheries Chamber was created. The secretary of the Chamber was Aleksander Määr (1901-69) and the investigations on fish and fisheries were directed by Edvin Reinvaldt (1890-1979). A number of scientific articles on salmon, trout, eel, grayling vendace, sunbleak, crayfish, fish parasites, seals, formation of fish fauna in Estonia, etc. were published in the Proceedings of the Fisheries Chamber (Ojaveer et al., 2000).

The first contacts of the Republic of Estonia with ICES were started by the Professor of the University of Tartu G. Schneider in 1920. He participated as a guest in the ICES meeting in Copenhagen in 1921. In 1923 Estonia (also Latvia and Poland) were accepted as the associated members (not paying regular

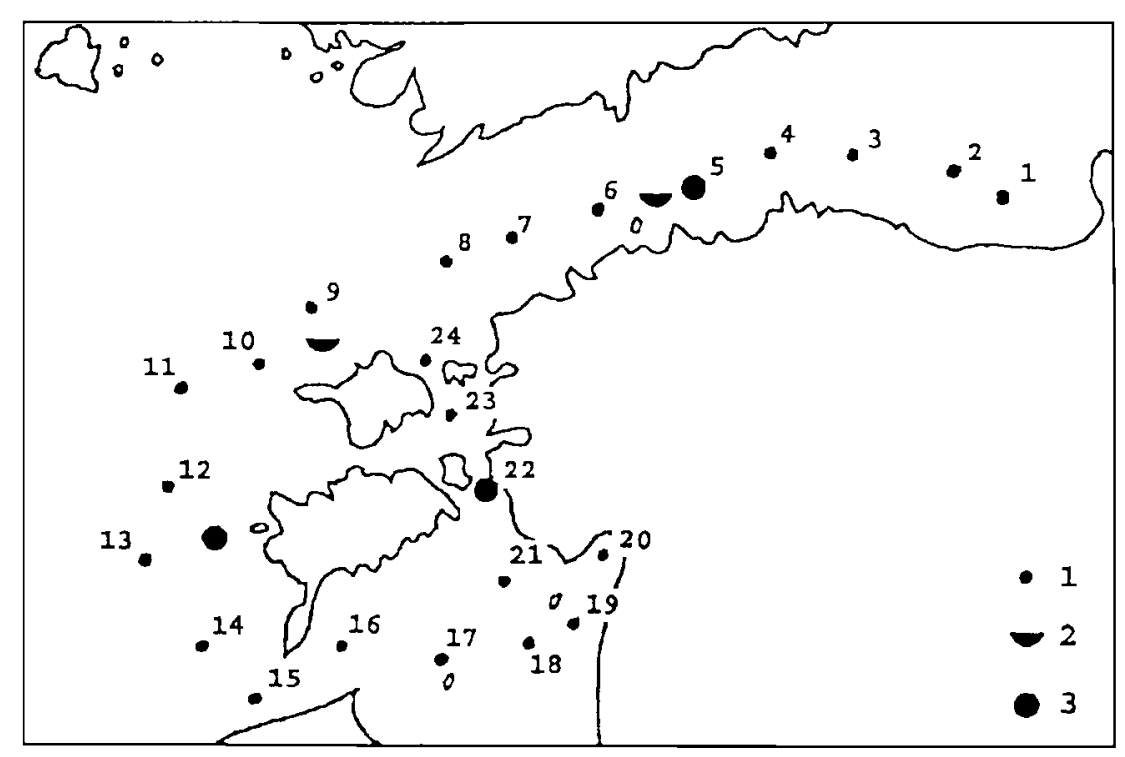

Fig. 1. Estonian stationary stations in the Baltic Sea in 1923-40: 1, monitoring stations visited annually; 2, lightships; 3, deepwater observation stations visited three times a month (Frisch \& Riikoja, 1925; Mardiste, 1999). 


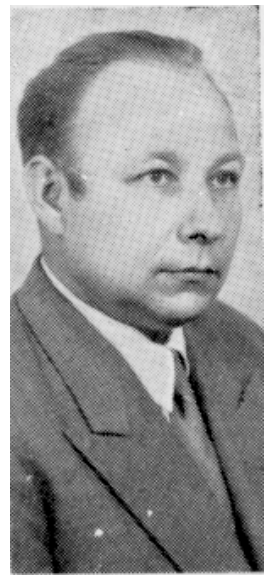

Fig. 2. Taivo Laevastu (born E. Granfeldt), a famous Estonian marine scientist, who succeeded in escaping the occupation. contribution and without the right to vote on administrative and financial matters). In 1926 Estonia withdrew from the Council (probably due to financial difficulties) but continued regular presentation of data on monitoring of meteorological, physical, and chemical parameters of the sea (up to 1939) and submitted some data on marine fish (Went, 1972; Ojaveer et al., 2000).

\section{DURING WW II}

In 1940, after Estonia was occupied by the Soviet Union, marine investigations were disrupted. During the German occupation of 1941-44 some investigations were performed under the leadership of Dr. E. Reinvaldt in the Exploratory-Experimental Laboratory of the Fisheries Division of the Agricultural Directorate. After the heavy bombing of Tallinn by Soviet aircraft on 9 March 1944, the Laboratory was evacuated to Taebla in West Estonia (about $10 \mathrm{~km}$ from the town of Haapsalu).

In August 1944 most marine researchers fled to Sweden and other democratic countries to escape occupation. Among them were Dr. Taivo Laevastu (Fig. 2), who later held important scientific positions in Sweden, in the USA (Honolulu, Monterey, Seattle), and FAO (Rome, Italy); A. Määr, who worked in Sweden and as a high fisheries officer in North Rhodesia; H. Toots, who had a post in fisheries management in South Rhodesia; Dr. E. Kägi; Dr. J. Lepiksaar; Dr. K. Kirde; Dr. E. Reinvaldt; L. Niit; Dr. A. T. Piip; Dr. H. Sandstöm; Dr. G. Roden; Dr. R. Weiler; and others. A number of them developed into well-known scientists in their field in global sense or in their new homeland. However, the loss of independence and the qualified and promising scientists was a heavy blow to both Estonian fisheries and marine research.

\section{UNDER SOVIET OCCUPATION}

\section{The Estonian Department of the All-Union Research Institute of Marine Fisheries and Oceanography (VNIRO)}

The Estonian Department of VNIRO was founded on 1 October 1944 (Fig. 3). It was the first separate institution for marine research in Estonia. The wellknown organizer of Estonian fisheries Georg Kask was among the founders of the Department. The first director of the Department was Neeme Mikelsaar (1910-90). Three laboratories (ichthyological, chemical-technological, and oceanological) were created. 


\section{Ulellianliso Herekalang Janduge ja Dokeanogranein TeadnsI1ku-Unimino Instl tuudl (VNIRO) Eesth Onakonna diektorl}

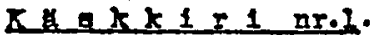

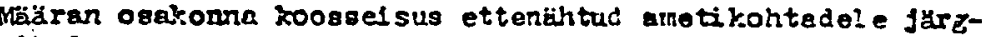
rlsed 1sikud:

1. Malmu, Juhan1 t. So o t $g^{\prime}$ a onakonna sekretdir-maginakirjutaja ajut1sek a kohustetaitjeks, arvaten 20.0k toobrist 1944.2. palg88a Rhl. 400.- kuus.

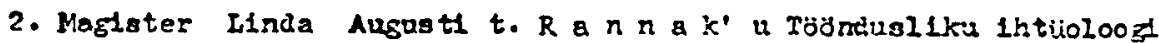
laboratoorlumi vanema teadusliku kasstodlige k.t.-ks, arvates 1.oktoobrist 1944.a., palgaga Rbk. 1.2 Co.- kuus

3. Albert, Jurl p. H ä r m' 1 - TBöndual1ku 1htioloogla laboratoo riwnt pisigltehnila vanema insener k.t.-ks, a rvates 15.oktoobrist 1944.a., galgeza Fbl. 900.- kuus.

4. Helene, Feetrl t. $V 11 \mathrm{~m} s$ e $\mathrm{r}^{*} 1$ - Töndusl 1htiol. laboret. van. Laborandt afutl seis kohuste täitjaks, a Frates l.ok 1944.a., pelgeza Rbl. 400.- kuus.

5. Alfred, $\mathrm{T} 1 \mathrm{k} \mathrm{s}^{\prime} 1 \mathrm{Kal}$ 'espatuse laboratoorlum. juhataja afutlse kohuste tä1tjaks, arrates 1.nnvembrist 1944.a., kun! 31. detseabrind 1944.8. - Foole pal Eaga Rbl . 500.- kulis, asukchega Tartu.

6. Martin, Eño p. $K$ a $\Omega d^{\prime} 1$ Tehnoloogilise laborato oriuni venema insener-tehnolooji k.t.-ks, arvates l.ncvembrist $1944 . \mathrm{A}$ palgaga $\mathrm{Rbl}$. 900.- kuus.

7. Voldemer, Jeanl p. $R \mathfrak{n} u a^{\prime}$ I osakorna direktor 1 abi majandusalal k.t.-ks, arvates $23.0 k t$ oobrist 1944.a.. palgaga Rbl.800 kisus.

8. Vande, Gustav1 $t$. I a s a raametukeguhotdja-tor ad $k . t .-k a, a r-$

$\because$ vates 15.0 octoobrist 1944.A., palgare Rbl. 700.- kius.

9. Kalfa, Aleksande p. $\mathrm{V}$ a 1 m $r$ a preparaator-muuseumihoidja ajus1seks kohuste taitfaks, arvates l.oktoourist 1941.a., pat gaga Rbi. $450 .-$ kuts.

10. Maie, Villemi t. $P$ ee $n$ B o o, korlstajaks, a rvates 1.0kt. 1944.a. palgaga RbL. $250 .-$ kuus.

- 3 " nov. 1944.8.

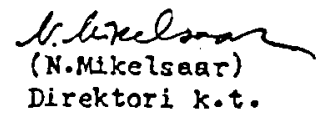

Fig. 3. The first order of the director of the Estonian Department of the All-Union Research Institute of Marine Fisheries and Oceanography appointing a staff of 10 . 
Systematic ichthyological investigations were started in the Estonian coastal sea. In 1946 and 1949 regular fieldwork on marine biology, studies on fish reproduction and larval abundance as well as on the spawning stock were carried out in the Väinameri. In 1947 the studies were performed in Pärnu Bay and around Kihnu Island, in 1948 at Kihnu. In September 1949 the first longer ichthyological cruise was made on board the MRT-158 Merilind in the Gulf of Riga. The staff, which included only some individuals who had earlier worked in the field of marine research (e.g. Dr. E. Reinvaldt), were getting the necessary experience and the studies developed successfully.

However, in the period of raging Lysenkism N. Mikelsaar was removed from his post and replaced by P. Sorokin. Under his leadership the research work was heavily depressed. To avoid a complete ruining of the investigations, the director of VNIRO V. Zaitsev asked L. Rannak (who had successfully organized herring studies) to accept the directorship. After the removal of P. Sorokin from the directorship on 1 February 1957 only five persons remained in the department. As a result of the efforts by L. Rannak, the Estonian Department was affiliated to the Institute of Zoology and Botany of the Academy of Sciences of the Estonian SSR as the Laboratory of Marine Ichthyology.

\section{The Laboratory of Marine Ichthyology of the Institute of Zoology and Botany}

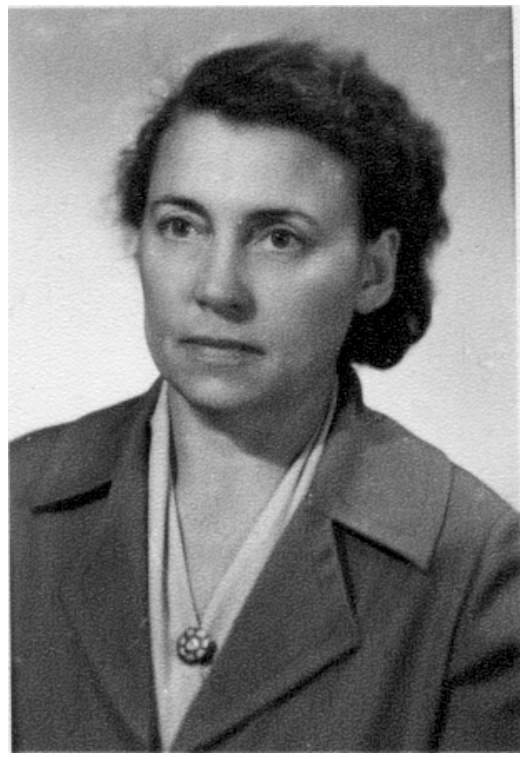

Fig. 4. Linda Rannak (1909-90), an outstanding Estonian marine scientist and leader of marine research.
Linda Rannak (Fig. 4), whose M.Sc. degree was attested to the Cand. Biol. degree in 1946, was a genuine scientific leader of marine research of that time in Estonia. She conducted several highlevel investigations (studies on herring embryology, larval abundance, and feeding, on stock assessment based on the abundance of year-classes and larvae, etc.) that were appreciated by leading scientists of these fields in the USSR and abroad. In 1970 she promoted her D. Biol. degree, being the first to receive a doctor's degree in a marine discipline in Estonia. Her studies allowed the introduction of herring from the Baltic Sea to the Aral Sea in 1954-56. The applied recommendations composed by her for fishery managers were well founded and highly appreciated. 
However, her most outstanding contribution to the Estonian marine science and Estonian culture was reorganization of Estonian research of the sea in the period of her directorship in 1957-62, and its affiliation to the Academy of Sciences of the Estonian SSR. She employed young scientists, graduates from the University of Tartu. This resulted in the formation of the Estonian staff of young scientists (Vaike Erm, Tiiu Pullisaar (Trei), Alide Lumberg, Arvi Järvekülg, Ilmar Sõrmus, Veera Shestakov (Kople), Toomas Takjas, Evald Ojaveer, etc.), who had been taught by professors of the University of Tartu Johannes Piiper, Heinrich Riikoja (Fig. 5), Juhan Aul, Liidia Poska-Teiss, August Vaga, and others, whose scientific and ethical standards were high. This staff was interested in local problems and was very active in the investigation and protection of the environment and living resources of

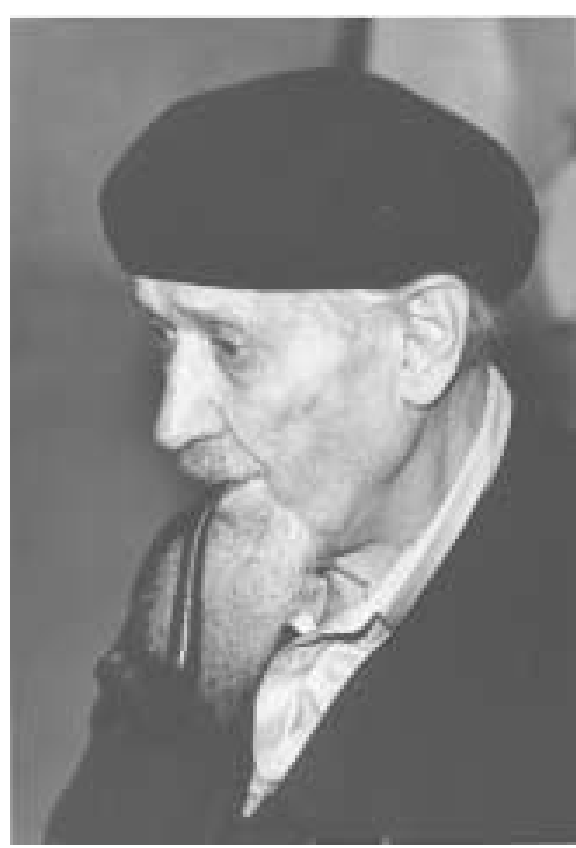

Fig. 5. Professor Heinrich Riikoja (18911988) in 1966 when visiting his former students in the Estonian Laboratory of Marine Ichthyology. the Estonian sea.

In the period 1957-62 important preconditions were created for future investigations (field bases in Pärnu and Kihnu and a research boat were obtained; studies on pikeperch, whitefish, smelt, bottom fauna, marine macrovegetation, and the effects of pollution were commenced; underwater investigations and application of computers and mathematical methods started).

\section{The Tallinn Department of the Baltic Fisheries Research Institute (BaltNIIRH)}

As a shock for the Estonian marine scientists, with the decree of the Council of Ministers of the USSR of 2 June 1962, the Estonian Laboratory of Marine Ichthyology was subordinated to the State Committee of Fisheries from 1 January 1963 and soon thereafter to the Baltic Fisheries Research Institute in Riga. With the change in subordination the opportunities to arrange research cruises improved. However, the transfer meant cutting important connections with Estonian systems. The rigid rules implemented by the new superiors allowed Estonian researchers to carry out only investigations directly connected with fisheries. 
With the change in subordination, L. Rannak resigned from her directorship. The following directors of the Estonian Laboratory of Marine Ichthyology/Tallinn Department of BaltNIIRH, were appointed from among such persons who were not capable of becoming scientific leaders of the staff. From 1 January 1963 to 10 October 1971 the director was a sprat specialist Ivar Veldre, Cand. Biol. After him the directorship belonged to Olev Leino, a graduate from Moscow Technical Institute of Fisheries. He resigned in January 1985 and his successor Mart Kangur, Cand. Biol., reigned up to the collapse of the Soviet regime in 1991.

During the directorship of O. Leino, an active supporter of fisheries, the number of the staff doubled, reaching 56 in 1976. A field base for the studies on aquaculture and fish diseases and parasites was established at Kõiguste (SE Saaremaa). The field base at the Sauga River in Pärnu was reconstructed.

O. Leino put much emphasis on the development of aquaculture and on the service of locally important farms and commercial enterprises. For this purpose several new structures were created in the Tallinn Department, such as the Section of Fish Diseases, the Section of Biochemistry, etc. Also, the Section of Mathematical Methods and the Section of Baltic Herring were formed.

During the 1970s and the first half of the 1980s the main scientific results of the investigations that had been started in the period 1957-62 became available. A number of theses were promoted, e.g. by Tiiu Trei (Cand. Biol., 1973), Mart Simm (Cand. Biol., 1976), Henn Kukk (Cand. Biol., 1980), Robert Aps (Cand. Biol., 1981), and Ahto Järvik (Cand. Tech., 1983). Estonian marine scientists made important contributions to the understanding of the mechanisms of the formation of the biological productivity of the Baltic Sea and of the structure and dynamics of bottom vegetation, zooplankton, and zoobenthos. Also, the biology, stock composition, and abundance fluctuations of Baltic herring, whitefish, pikeperch, vimba bream, smelt, and other fishes were studied and recommendations for their management in the Baltic Sea and Estonian coastal areas were made. A number of scientific works were written, some of them together with scientists from neighbouring countries (M. Kalējs, M. Vītiņš, O. Rechlin, K. Strzyzewska, etc.).

In marine science international cooperation is extremely important. Under Soviet rule it was complicated to organize and participate in such cooperation. However, some Estonian marine scientists (e.g., A. Järvekülg, A. Lumberg, V. Astok) succeeded in participating in the collaboration between the USSR and Finland in the investigations of the effects of pollution and protection of the Gulf of Finland. They developed good cooperation with their Finnish colleagues Dr. Aarno Voipio, Dr. Paavo Tulkki, Dr. Åke Niemi, and others.

In ichthyology and fisheries science, publication of short Estonian papers in the ICES issues started in the 1950s. In 1960 L. Rannak attended the ICES Statutory Meeting in Moscow. Estonians participated in the ICES 59th Statutory Meeting in Helsinki in 1971. In the symposium prior to the meeting some of their findings on the factors determining the abundance of recruitment in spring 
spawning herring of the Eastern Baltic and on the mortality rates of herring seasonal races were presented. Since 1974 Estonian fisheries scientists have participated regularly in the meetings of the ICES Working Group on Assessment of Pelagic Stocks in the Baltic. The joint work with colleagues from other Baltic Sea countries (e.g. Prof. V. Sjöblom and Dr. R. Parmanne from Finland, Dr. A. Lindquist from Sweden, Dr. O. Rechlin from the GDR, Prof. F. Thurow from the FRG, Prof. J. Popiel and Dr. J. Elwertowski from Poland) and others was of great practical importance in the creation of the basis for management recommendations and corresponding decisions by the national bodies and the International Baltic Sea Fishery Commission.

In addition to the Tallinn Department of BaltNIIRH, two Estonian scientific institutions performed investigations of the Baltic Sea: the Section/Department of the Baltic Sea at the Institute of Thermophysics and Electrophysics, established in 1972, and the Section of Marine Biology at the Institute of Zoology and Botany of the Academy of Sciences of the Estonian SSR, established in 1974. Also a large system of hydrometeorological service has existed with the main duty to carry out monitoring, including in the sea areas. Based on this work, a number of scientific publications have appeared (e.g. Lenskaya, 1965). Some research papers have been published by marine scientists working at the University of Tartu (Mardiste, 1999; etc.).

\section{Oceanographic investigations in the system of the Academy of Sciences of the Estonian SSR}

The Section of the Baltic Sea of the Institute of Thermophysics and Electrophysics of the Academy of Sciences of the Estonian SSR, headed by Prof. A. Aitsam, Dr. Phys.-Math., was created on 2 October 1972. By the beginning of 1990 the Section had expanded into the Department of the Baltic Sea with several sections, the Pärnu Field Base, and a total staff of 123. This institution had rich financial support from both the all-Union and Estonian SSR sources. The vessel Ayu Dag (63.8 m, 1001.88 brt.) was received from the Black Sea Fleet in 1976 and rebuilt into a research vessel in France. In 1984 a new research vessel (Arnold Veimer, $71.6 \mathrm{~m}, 1832$ brt., speed 14 knots), specially designed for the Department, constructed in Turku, Finland, made her first cruise. The scientists had at their disposal good equipment: gas and liquid chromatographs, atom absorbtion and fluorescence spectrophotometers, current recorders, various samplers, etc. The Department carried out investigations in marine physics, chemistry, and biology both in the Baltic Sea and the Atlantic Ocean. During the existence of this unit nine Cand. Sci. degrees were promoted (among others by Tiit Kullas, 1980; Jaak Heinloo, 1981; Jüri Elken, 1983; Aleksander Toompuu, 1984), two monographs and over 300 research papers were published. 
On 4 January 1990 the Institute of Ecology and Marine Research of the Academy of Sciences of the Estonian SSR was established. The departments of Marine Physics, Marine Chemistry, and Modelling of Marine Systems, as well as other groups connected with marine research and the vessels, were transferred to the new institute from the Institute of Thermophysics and Electrophysics and the Department of Marine Biology of the Tallinn Department of BaltNIIRH. The existence of the Institute was rather short - in 1992 it was split into two parts, one of which was incorporated into the Estonian Marine Institute.

\section{Marine biological investigations in the system of the Academy of Sciences of the Estonian SSR}

The Section of Marine Biology of Institute of Zoology and Botany of the Academy of Sciences of the Estonian SSR with Arvi Järvekülg, Cand. Biol. as the head was created on 16 July 1974. The Section carried out investigations chiefly on the composition and dynamics of planktonic and benthic communities in comparatively clean and polluted Estonian coastal waters (Haapsalu and Matsalu bays, Gulf of Finland). It also participated in the research of the Baltic Proper on board the Ayu Dag and Arnold Veimer. In the Section one D. Biol. thesis (A. Järvekülg, 1975) and several Cand. Biol. and M.Sc. theses were promoted. Since 1991 the section transferred to the research of the Estonian rivers and closed its marine studies (A. Järvekülg, pers. comm.).

\section{IN INDEPENDENT ESTONIA}

The Tallinn Department of BaltNIIRH was reorganized to become the Estonian Fisheries Institute on 6 January 1992. Ahto Järvik, Cand. Tech., was appointed director of the Institute. The establishment of the Institute gave an opportunity to concentrate Estonian marine research to give the rather expensive marine science in the complicated economic situation a better chance for survival.

The Estonian Marine Institute was established on 3 July 1992 on the basis of the Estonian Fisheries Institute and the marine subdivisions of the Institute of Ecology and Marine Research, a total of 140 individuals. A. Järvik, put up by the Estonian Academy of Sciences, was elected director of the Institute. During its existence the Estonian Marine Institute has substantially changed. Large (and expensive) research vessels have disappeared. The staff has decreased - some former research fellows or assistants are now working in other spheres of life or have found better opportunities abroad. Still, the principal goal of the activities of the Institute - investigation of the structure, functioning, and dynamics of the Baltic Sea ecosystem and its subsystems - has remained unchanged. 
In 1998, after A. Järvik's term in office ended, Toomas Saat, Professor of the University of Tartu, was elected director of the Estonian Marine Institute. He performed major rearrangements in the Institute to improve conditions for scientific research and applied work. Since 1999 the Institute employs about 85 individuals belonging to four sections:

1. Section of Marine Physics headed by Prof. J. Elken, Cand. Phys.-Math.;

2. Section of Marine Biology headed by G. Martin, Ph.D.;

3. Section of Fisheries Research headed by Prof. T. Saat, Cand. Biol.;

4. Section of Modelling of Marine Systems headed by R. Tamsalu, D. Phys.Math.

The Institute has field bases in Pärnu and at Kõiguste, SE Saaremaa. The amount and the quality of scientific production of the institute are increasing. In January 2001 the Estonian Marine Institute was affiliated to the University of Tartu. This important decision in the history of the development of Estonian marine research substantially improves the scientific background of the Institute as well as the opportunities to prepare postgraduates for a career in marine research.

The Institute participates in a number of domestic and international research projects. It represents Estonia in several international marine organizations. In 1994 Estonia became the 19th full member of ICES in St. John's, Canada. It has been decided that in 2003 the Annual Science Conference of ICES, one of the most outstanding events of the year in marine science, will be held in Tallinn, Estonia.

APPENDIX

\section{HISTORY OF ESTONIAN MARINE AND FISHERIES INVESTIGATIONS}

1 st half of the Investigation of remote (mainly polar) seas

19th century (A. J. von Krusenstern, F. G. von Bellingshausen,

O. von Kotzebue, F. von Wrangel, etc.)

1805 Beginning of measurements of water level in the Tallinn Port

1840s Determination of water salt content in Tallinn and Haapsalu bays

1851 The first comprehensive study of possible overexploitation of marine fish stocks in the world (K. E. von Baer)

1884 The first expedition for the exploration of Estonian marine waters

1921 Composition of programmes for marine investigations (Estonia, Finland, Latvia)

1923 Admission of Estonia (as an associated member) to ICES

1923-24 Beginning of monitoring of Estonian marine waters (K. Kirde, H. Riikoja) 
Appearance of the first monthly fisheries journal in Estonia

Establishment of the Fisheries Chamber

Foundation of the Estonian Department of the All-Union Research Institute of Marine Fisheries and Oceanography

1957-62 Affiliation of Estonian marine science to the Academy of Sciences of the Estonian SSR

1962 Appearance of the world's first textbook/handbook on the Fisheries Oceanography (T. Laevastu and I. Hela)

1963-91 Subordination of the Estonian Laboratory of Marine Ichthyology to the Baltic Fisheries Research Institute (Riga)

1972 Establishment of the Section of the Baltic Sea of the Institute of Thermophysics and Electrophysics of the Acad. Sci. of the Estonian SSR

1974 Establishment of the Section of Marine Biology of the Institute of Zoology and Botany of the Acad. Sci. of the Estonian SSR

1984 The first cruise of the R/V Arnold Veimer (Livonia)

\section{REFERENCES}

Baer, K. E. von. 1860. Investigations on the State of Fisheries in Russia. Part I. Fisheries in Lake Peipsi and Pskov and in the Baltic Sea. St. Petersburg (in Russian).

Braun, M. 1884. Physikalische und biologische Untersuchungen in westlichen Theile des finnischen Meerbusens. Archiv für die Naturkunde Liv-, Ehst- und Kurlands. Dorpater NaturforscherGesellschaft. Zweite Serie. Biologische Naturkunde, Bd. X, Lieferung 1.

Frisch, K. \& Riikoja, H. 1925. The thalassological cruises in the Estonian seas in 1923 and 1924. Tartu Ülikooli Eesti Veekogude Uurimise Komisjoni Väljaanne, 2.

Kirde, K. 1940. The thalassological cruises in the Estonian seas in 1935-1939. Loodusvarade Instituudi Avaldised (Tallinn), 3.

Lenskaya, O. A. 1965. On arrangement of the results of observations on sea level in the Estonian SSR. Sb. rabot Tallinskoi gidrometobserv., 3, 76-84 (in Russian).

Mardiste, H. 1995. Eestit piirava mere hüdroloogilise uurimise ajalugu (kuni 1917. aastani). In Teaduse ajaloo lehekülgi Eestist. XI kogumik, pp. 58-78. TA Kirj., Tallinn.

Mardiste, H. 1999. Eesti rannikumere hüdroloogiline uurimine aastail 1918-1940. In Year-Book of the Estonian Geographical Society, Vol. 32, pp. 80-89. Estonian Academy Publishers, Tallinn.

Ojaveer, E., Rannak, L. \& Laevastu, T. 2000. One and a Half Centuries of Sea and Fisheries Investigations in Estonia. Estonian Academy Publishers, Tallinn.

Went, A. E. J. 1972. Seventy years agrowing. Rapp. P. - v. Reun. Cons. int. Explor. Mer, 165. 


\section{EESTI MEREUURINGUTE AJALUGU}

\section{Evald OJAVEER}

Eesti mereuuringute alguseks võib pidada 18. sajandit, kui peamiselt baltisaksa päritoluga meresõitjad uurisid eeskätt polaarmeresid. Meretaseme, soolsuse ja temperatuuri määramised Eesti vetes algasid 19. sajandi esimesel poolel, põhjataimestiku, kalade ja kalanduse vaatlused mainitud sajandi keskpaiku. Iseseisvas Eestis arenenud kalandusteaduslikud ja okeanograafilised tööd lõpetas Nõukogude okupatsioon. Teise maailmasõja lõpul põgenes enamik Eesti mereteadlasi välismaale. 1. oktoobril 1944 asutati Üleliidulise Merekalamajanduse ja Okeanograafia Teadusliku Uurimise Instituudi Eesti Osakond, mida juhtis N. Mikelsaar. Lõssenkismi märatsemise järel tõi osakonna direktor L. Rannak säilinud mereuurijad Eesti Teaduste Akadeemia alluvusse ning töölevõetud Tartu Ülikooli lõpetanutele toetudes kujundas uuringud ümber. Hoolimata hilisematest Moskva ja Riia asutustele allutamistest säilis meie kalanduslikus mereuurimises tugev Eesti-kesksus. Suur, peamiselt merefüüsikutest koosnev Läänemerd ja Atlandi ookeani uuriv kollektiiv arenes 1972. aastast alates ENSV TA Termoja Elektrofüüsika Instituudis. Rannikumere uurimiseks moodustati 1974. aastal Zooloogia ja Botaanika Instituudis merebioloogia sektor. Taasiseseisvumise järel koondati mere füüsikalised, keemilised, bioloogilised ja kalanduslikud uuringud 1993. aastal loodud Eesti Mereinstituuti, mis 2001. aastal ühines Tartu Ülikooliga. 